\title{
A NOTE ON PROFESSOR RUNDELL'S COMMENT
}

\author{
CHARLES E. CLARK $\dagger$
}

Professor Rundell confines himself to some policy generalizations and eschews the cases. Initially, such restriction of subject matter might have been permissible; I, for one, have always considered policy more important than mere precedent. But it is the Institute which makes case law its god and even cites this very Restatement as a demonstration of its "fundamental policy" to accept existing law, "not to make it"; and Mr. Rundell himself has continuously rested upon the compulsion of the cases. Since my own case study pointed to other conclusions and since I had seen no convincing grouping of cases marshalled behind the Restatement, I took the initiative of making a collection of cases so complete that the reader could draw his own conclusions. The drudgery of this documentation is now turned off with the statement that this is "excellent source material for a study of section 82"-no reference being made to section 85 , which, it is true, I believe to be wholly unsupported by precedent; and then my conclusions as to the specific cases are assailed by unannotated characterizations of my supporting authority as "negligible in number and the converse authority overwhelming," with "such an amount and such a unanimity of American authority" for 82 as to make it mandatory, irrespective of history and social desirability, and with "authority and good sense" for 85. I do not believe Mr. Rundell expects to rebut the citation of specific cases by such daring generalizations, and think the key to his proffered rebuttal is found in his statement that he approaches discussion of this, to my mind, purely intellectual disagreement "with reluctance." Had I not already experienced the Institute's unwillingness, nay, rather inability, to be even aware of, much less to consider, opposing viewpoints, I should have supposed that such intellectual jousting would have been approached with a measure of joy and eagerness.

In the face of charges at once so broad and so undetailed, there is nothing I can do except ask the reader to return again to a consideration of the cases I cited in my article. ${ }^{1} \mathrm{He}$ will find, I think, that even though I have not believed in the various small distinctions in the cases which Mr. Rundell stresses, because they seem to me so largely procedural, only pseudo-historical, and far from the normal reactions of property owners, and because I cannot find them stressed in the cases themselves, yet I have considered them all and still prove the authorities lacking in really

$\doteqdot$ United States Circuit Judge, Second Circuit Court of Appeals.

1. The American Law Institute's Law of Real Corinants (1943) 52 YaLE L. J. 699, with an appendix of American privity cases at 731-36, a tabulation and classification of cases particularly at 717-21, and an appendix dealing with the Institute's treatment of this subject and of opposing views at 737-38. 
general support of either of the two conflicting branches of the privity section (82) or any actual support of the attempt there made to couple them as a team. And as to section 85, not only are cases lacking for it; but certain lines of authority, such as the important party-wall cases, with benefit personal, while the burden runs, show how erroneous it is. ${ }^{2}$ Incidentally, I understand a late redraft of this section leaves out all reference to the doctrine of "touching and concerning," a confession that the well known and familiar precedents cannot be stretched to its support, but also a highly unfortunate departure from settled and desirable law. For that doctrine, while a bit metaphorical in statement as the old common law usually tended to be, nevertheless states a rational requirement of connection between land and promise which was readily understood and accepted by land takers; and though its edges may be indefinite, its solid central core has been so often defined as to make generally undisputed the running of the ordinary and important covenants-those for fencing and repairs, party walls, irrigation, and water rights. As the roll of citable cases shows, all such normal covenants overwhelmingly do run in American law; it is the height of unreality to state vague restrictions which acquire constent only from the adjudication of an appellate court on a particular case, thus rendering all covenant titles unmarketable. ${ }^{3}$

So, also, as to policy, Mr. Rundell's abstract statements, which do not come to grips with his specific restatements, leave little of which to take hold. If we are to be governed by the dictum of a New Jersey judge many years ago, expressing vague and unreal fears of encumbrances "as multiform and as innumerable as human caprice" (does this really describe a a party-wall covenant or an irrigation agreement?), why should we not then go logically to the rationally supportable rule announced in New Jersey and a few other jurisdictions that the burden does not run at all? I think that more defensible than a rule which says it does run, but under circumstances so indefinite as to be unpredictable. I see nothing in the old separation of chancery and law which says that covenants should not

2. See, e.g., id. at 719-20. The one case here cited by Mr. Rundell as support for section 85, Orenberg v. Johnston, 269 Mass. 312, 168 N. E. 794 (1929), shows the correctness of my inference that section 85 was but an expansion to limits entirely indefinite, in view of its matching of values between obligor and obligee, of a rule stated in section 82 as not an absolute prohibition, but only as an alternative requirement. For the Orculberg case states and relies on only the usual Massacliusetts rule that the coventunt must be in aid of an easement, as per section 82 (a).

3. It is surprising to find Mr. Rundell solicitous of title marketability, for it had seemed a part of his intent, just as in his restatement of easements in gross (see Clark, supra note 1 , at 715 ), to lessen use of covenants by making them uncertain. Actually, outside of the special situations of California, Massachusetts, and New York (and even there the majority ran), the count was 88 cases of running covenants to 11 held personal, i.c., not touching or concerning, on rational and understandable grounds, and only 5 where running was refused. See id. at $720-21$. 
be the servant of man, used where useful, rather than that fear of "human caprice" should paralyze their use. As to the truism that men are not bound by contractual promises against their will, a long history going back to the early Year Books demonstrates (notwithstanding its summary discounting by Mr. Rundell) that these interests have been viewed and enforced as land obligations some centuries before the legal recognition of simple contracts. And my reference to liens is misunderstood. I consider the lien a quite useful remedy in its place; its limited applicability here makes its parading in the Restatement but a sly bit of red herring to cover up the destruction of important property interests by denial of an appropriate for a practically illusory remedy."

I planned my article as a case study of Institute juristic methodology. It seems to me Mr. Rundell's rebuttal is prime source material for such a study. His present disclosure of his policy preconceptions, together with his impatience with a presentation of opposing case material, shows how the Institute in last analysis is bound to its reporters' preconceptions, with the much vaunted case authority providing at best only a kind of remote point of departure. It helps to explain, too, why those of us who cannot go along intellectually get shrift which is short, indeed, when the Institute machinery moves. After all, the Institute is a private organization, and there is no law to force it to any other course; the question still recurs whether the product thus fashioned is to be taken as the authentic expression of American legal thought.

4. Because liens, except for routinized security devices, such as mortgages, and a few special statutes, are in our ordinary law merely means of enforcing money judgments already rendered, not steps to the judgment itself. Even agreements for liens are rather unusual, probably because such liens, while valid for fixed recurring charges like mortgages, are of quite doubtful validity for indefinite contractual breaches and are undoubtedly feared for their possibly extensive and uncertain incidence. Here Mr. Rundell departs from the course he has elsewhere set himself to cite all the cases, thus showing how limited they are. It is to be noted that where the cited reference is more than purely incidental, the lien depends either on statute (California, Nebraska) or on express agreement (New York); further, that the single Texas case cited (far from representative of general Texas law, see Clark, supra note 1, at 736) and Whittenton MIfg. Co. v. Staples, 164 Mass. 319, 41 N. E. 441 (1895), actually hold the interest involved to be an easement, i.e., a much more drastic and extensive obligation than any for which I have contended. But as pointed out in Clark, supra at 733, this is one definite course talien in Massachusetts to evade its otherwise harsh doctrine. 